adjust them in such a way as to meet the need, not for immediate gain so much as for an enduring advance from which future generations might gain enhanced opportunities of expression of the best aspects of their personalities. His civic improvements at Edinburgh, his betterment of Indian cities, his efforts for residential halls for British students in French universities with the view of international understanding, and, perhaps most intimately of all, his gardens, were all the expression of the idealism that was the dominant note in a noble character.

\section{DR. L. A. BAUER}

Dr. Louis Agricola Bauer, who was killed on April 12, by falling from a window of his flat in Washington, was probably the best-known authority on terrestrial magnetism in the world. Born in Cincinnati, on Jan. 26, 1865, he was educated at the university there, and in Berlin. From 1887 until 1892 he was astronomer and magnetic computer in the U.S. Coast and Geodetic Survey, and in 1895-96 was an assistant to Michelson at Chicago. There he founded the journal Terrestrial Magnetism (the words and Atmospheric Electricity being added to the title in 1898) ; this was then, and still is, the only periodical expressly devoted to the subject. He conducted the journal for many years on his own financial responsibility, occasionally assisted by grants.

In 1896, Dr. Bauer began a magnetic survey of Maryland, under the State geologist-this was the only State magnetic survey that had been undertaken for many years; he continued the survey during two or three summer vacations, and published a very interesting historical account of terrestrial magnetic observation in his first report on the Survey. In 1897 he became assistant professor of mathematics and mathematical physics at Cincinnati. His enthusiasm for terrestrial magnetism, and his energetic pursuit of magnetic work, aroused renewed interest in the subject in the United States, and in 1899 he rejoined the Coast and Geodetic Survey as chief of the newly founded Division of TerrestrialMagnetism. Thereheinitiated an active policy, planning a magnetic survey of the whole of the United States and its territories elsewhere, and, in connexion therewith, instituting four new magnetic observatories, at Cheltenham in Maryland, Baldwin in Kansas, Sitka in Alaska, and Honolulu in Hawaii. He also greatly developed the magnetic work of the ships of the Coast and Geodetic Survey. Though he did not long remain in his new office, his influence on the work of the Coast and Geodetic Survey has been lasting, and the Survey is now one of the most active national organisations undertaking magnetic observatory and survey work.

Bauer's ambitions for his chosen science did not stop short at national frontiers, however; he saw that the science needed a world magnetic survey, and that, on account of the irregular and incalculable course of the secular variation, this survey must be renewed every generation, unless important data are to be for ever lost. He saw also that this could not be achieved by national organisations, so many countries being scientifically backward, while many parts of the oceans had long remained unsurveyed. He therefore drew up a plan for a research department of terrestrial magnetism, which should fill up what was lacking in the efforts made by other magnetic organisations, as regards the world survey, and also do everything possible in other ways to advance the science. His plans led to the formation of the Department of Terrestrial Magnetism of the Carnegie Institution of Washing ton, in 1904; he became the first director, and held the office until he retired through ill-health, in 1930. Under his energetic direction, and with the aid of a devoted staff that he gathered round him, the Department has done a great work for terrestrial magnetism and atmospheric electricity. Perhaps its most important work was done by its two survey ships, first the Galilee, and later the non-magnetic ship Carnegie (unhappily destroyed, with the loss of its commander, Capt. Ault, in 1929, at Apia, Samoa). Much land magnetic surveying was also done, either directly or by aid given to other bodies. Iater the Department instituted two magnetic observatories, at Watheroo in Western Australia and Huancayo in Peru, to mitigate the pressing need for more magnetic observatories in the southern hemisphere. A valuable feature of the ocean survey work was the promptness of publication of the results, which enabled the various national ocean magnetic charts to be greatly improved in many respects. In many other directions also the Department carried out important work, which is still continuing and developing.

In his attempts to elucidate the theoretical aspects of the science Bauer was less successful, but it is well known that the subject is a particularly intractable one. His organising work, and its valuable and permanent results, will assure him a lasting and distinguished place in the roll of benefactors to the science; and his services to it were widely recognised in his lifetime, particularly by his election, in 1927, to the presidency of the international organisation for terrestrial magnetism, under the International Union for Geodesy and Geophysics.

S. C.

\section{We regret to announce the following deaths :}

Mr. B. A. Behrend, consulting engineer to the Westinghouse Electric and Manufacturing Co., Boston, Mass., a distinguished American engineer interested particularly in alternating current phenomena, on March 25, aged fifty-six years.

Sir David Drummond, C.B.E., emeritus professor of medicine at the University of Durham College of Medicine, past president of the British Medical Association, a well-known specialist in diseases of the brain, on April 27, aged seventy-nine years.

Dr. Victoria Hazlitt, lecturer in psychology, Bedford College, University of London, for some years secretary of the Committee for Research in Education of the British Psychological Society, on April 19.

$$
\text { No. 3263, Vou. 129] }
$$

